\title{
Next Generation Science Standard in Science Learning to Improve Student's Practice Skill
}

\section{Eka Rachmawati}

Postgraduate student of Science Education, Yogyakarta State University, Indonesia, ekarachma95@gmail.com

\section{Anti Kolonial Prodjosantoso}

Prof., Ph.D., Postgraduate Lecture of Science Education School of Education, Yogyakarta State University, Indonesia, prodjosantoso@uny.ac.id

\section{Insih Wilujeng}

Dr., M.Pd., Lecture Postgraduate of Science Education, Yogyakarta State University, Indonesia, insihwilujeng@uny.ac.id

The Next Generation Science Standard (NGSS) is an educational standard used in the United States. It is also used in Indonesia because it has characteristics similar to Curriculum 2013, which is used today. This standard is adapted in science learning because it is expected to easily measure students' processing skills in a specific theme. Science learning by a process must be measured by students' specific skills and comprehension. This study aims to reveal the feasibility of NGSS-oriented science learning tools. The tools are lesson plans, science worksheets, and assessments of the developing and using model skills through observation. To improve the skill of developing and using models using NGSSoriented learning tools, we made quasi-experiment with one experiment and one control group. The developing and using models skill data were obtained by an observer through an observation sheet during the science learning process. The obtained data is further analysed to obtain a score which showed that the developing and using models skill of the experimental class, i.e., 3.69 is higher than that that of the control class, i.e., 1.58. The results include the validation of NGSS-oriented learning tools scored by experts, science teachers, and students in preliminary field testing.

Keywords: learning tools, NGSS, practice skill, developing and using models skill, crosscutting concept

Citation: Rachmawati, E., Prodjosantoso, A. K., \& Wilujeng, I. (2019). Next Generation Science Standard in Science Learning to Improve Student's Practice Skill. International Journal of Instruction, 12(1), 299-310. https://doi.org/10.29333/iji.2019.12120a 


\section{INTRODUCTION}

The development of science and technology in the 21st century is advancing rapidly and tends to be uncontrollable. Such development requires humans to have life skills in the midst of increasingly globalized competition. Science and technology that develops quickly can be balanced with the various skills required to meet the challenges of the 21 st century; they can be prepared through qualified human resources that can be obtained through education. Next Generation Science Standards (NGSS) are developed based on the situation of students worldwide, who are undergoing very rapid changes. To meet this standard, teachers must plan learning that helps students to be ready to pursue further education or a career. NGSS is a standard K-12 curriculum of the United States that contains a set of science skills and knowledge that students are expected to master in an integrated manner. It has an innovative structure that combines aspects of skills, understanding, and content into three dimensions: scientific and engineering practice, crosscutting concept, and core idea (Bybee, 2014). Building core ideas, scientific and engineering practices, and crosscutting concept across time will support the development of scientific dispositions so that students know when and how to seek and build knowledge (Krajcik, 2014).

In 2016, formal education in Indonesia began using Curriculum 2013, which replaced the Education Unit Level Curriculum (SBC). This curriculum change was aimed at not only cognitive but affective or psychomotor learning as well as achieving a balanced competency between attitudes and skills with holistic and fun learning (Depdiknas, 2016).

The 2013 curriculum has the same goals as the NGSS in science learning in schools, which is to maximize students' practical skills, through student-centred learning and teachers as mentors. However, in the 2013 curriculum, the skills to be cultivated are too complex and teachers find it difficult to assess them. Bybee (2014) explained the NGSS includes eight skills, each of which has a development model, seven crosscutting concepts, and core ideas or content, all of which are bonded together. 
Table 1

Framework of Next Generation Science Standard

\begin{tabular}{|c|c|c|c|}
\hline \multicolumn{4}{|c|}{ The Foundation Box and Connection Box } \\
\hline \multicolumn{4}{|c|}{$\begin{array}{l}\text { Performance Expectation: } \\
\text { Using models, the students can identify the human respiratory system mechanism based on the structure } \\
\text { and system function of each parts. }\end{array}$} \\
\hline $\begin{array}{c}\text { Science and Engineering } \\
\text { Practice Skill (SEPS) }\end{array}$ & & Core Idea $(\mathrm{CI})$ & Crosscutting Concept (CC) \\
\hline Developing and using models & & uman respiratory system & Structure and function \\
\hline $\begin{array}{l}\text { 1. Use a simple system } \\
\text { model with definite and } \\
\text { predictable factors } \\
\text { 2. Develop or modify a } \\
\text { model (based on evidence) } \\
\text { to match what happens if } \\
\text { a system variable or } \\
\text { component changes }\end{array}$ & & $\begin{array}{l}\text { Analyse the respiratory } \\
\text { system in humans and } \\
\text { understand the disorders } \\
\text { of the respiratory system } \\
\text { as well as efforts to } \\
\text { maintain the health of the } \\
\text { respiratory system }\end{array}$ & 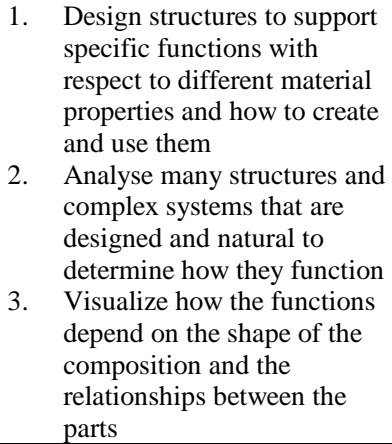 \\
\hline
\end{tabular}

The models are a representation of reality that describes the structure and order of a concept and displays one of four forms: verbal or conceptual description, action or procedure steps, physical or virtual replica, and equations or formula (Atawi, 2014).

Science often involves the construction and use of various models and simulations to help develop an explanation of natural phenomena. The model allows one to observe and imagine explanations of a phenomenon. Engineering uses models and simulations to analyse existing systems in order to see possible flaws or test possible solutions to new problems (NRC, 2014). Instruction about models should include thinking about the epistemology of models, developing visual spatial skills, practicing analogue-target mapping, identifying the strength and limitation of models, and thinking about how models are human inventions (Gustafon, 2014).

Developing and using models is one of the skills or knowledge developed in NGSS. It can analyse a system and allows students to explain a natural everyday phenomenon by using a clear concept or analogy. Explanations can be given using diagrams, replicas, analogies, math, and simulations (Duschl, 2013).

In science, a model is used to represent a system to be studied to help develop questions and explanations, produce data that can make predictions, and to communicate ideas to others (Anindityas, 2012). Students are expected to evaluate and refine a model through an iterative cycle to compare their predictions with the real world and then adjust them to gain knowledge of a modelled phenomenon. Thus, the model is based on evidence and, when new evidence is found that the model cannot explain, it is modified (NRC, 2007). 
Jancarikova (2016) explained the model used to support learning in cognitive achievements is divided into several levels: (1) The model can represent the real object, through direct learning, by holding the object and knowing the functions and processes that occur, (2) by learning objects and acquired knowledge (analysis and synthesis of knowledge), followed by the construction of new concepts in their minds, (3) By developing abstract thinking models, students learn to discover the structure of morphology (isomorphism). At the middle-school level, the skills of developing and using models emphasize: (1) Evaluation of the model's limitations for the proposed object or tool, (2) Development or modification of a model (based on evidence) to compare what happens if a system variable or component changes, (3) Use or development of a simple system model with certainty and factors that can be less predictable, (4) Development or revision of a model to show the relationship between variables, including those that cannot be observed but predict the visible phenomenon. Development or use of a model to predict and describe phenomena (6) Development of models to describe unobserved mechanisms, (7) Development or use of a model to generate data that can test ideas about natural phenomena or design systems, including those representing inputs and outputs on an unobserved scale (NRC, 2008).

The developing and using models skill is intended to emphasize or represent, in terms of science or engineering, the visualization of something abstract becoming more concrete or to understand a phenomenon to find the best solution for a problem by Bybee (2014). Based on some of these meanings, developing and using models are skills that students can use to understand an abstract system so that the model can be made to be more concrete, like replicas, diagrams, mathematical formulas, analogies, and computer simulations. In addition, some of the skills mastered by the students include: (1) the ability to analyse and even evaluate the model / visuals being used, (2) ability to use a simple system model to find predictable factors. (3) ability to float or revise a model to show the relationship between variables, including models that cannot be observed but can predict apparent phenomena, and (4) development of a model (based on evidence) to compare what happens if a system variable or component changes. This skill assessment is conducted on the experimental and control class. In skill assessment, there are several criteria derived from the indicators contained in Table 2. 
Table 2

Description of the Developing-Using Models Skill in Science Learning

\begin{tabular}{|c|c|c|c|}
\hline No & Aspect & Indicators & Criteria \\
\hline 1. & Using & $\begin{array}{l}\text { Use a simple system model } \\
\text { to find predictable factors }\end{array}$ & $\begin{array}{l}\text { a. Describe a model verbally or } \\
\text { conceptually } \\
\text { b. Understand the activities or } \\
\text { procedural steps of a model } \\
\text { c. Obtain data to make a prediction } \\
\text { or hypothesis } \\
\text { d. Recognize the weakness of an } \\
\text { existing model }\end{array}$ \\
\hline 2. & Developing & $\begin{array}{l}\text { Develop or modify a model } \\
\text { (based on evidence) to match } \\
\text { what happens if a variable or } \\
\text { component of a system is } \\
\text { changed }\end{array}$ & $\begin{array}{l}\text { a. Create a replica, real or virtual, } \\
\text { that can model a system } \\
\text { b. Create questions related to the } \\
\text { model to be created } \\
\text { c. Change variables that can change } \\
\text { results } \\
\text { d. Make a conclusion of the } \\
\text { relationship between the variables } \\
\text { based on the existing model }\end{array}$ \\
\hline
\end{tabular}

There are many advantages of the NGSS standard - it considers individual differences, introduces progress in knowledge and science as a way of research where the student progresses from micro to macro learning, motivates the student to use his mental processes, and focuses on the development of multi-thinking skills based on thrill and excitement to attract attention. It also depends on explanation and interpretation, discussion and collaborative learning, and detailed expansionist thinking, makes learning meaningful and helps correct understanding errors, and provides the student with several different ways of evaluation. Morphologically realistic model of the human respiratory tract from the nares to the alveoli has been developed that simulates inhalation, deposition, and exhalation of contaminants (Rosati, 2013).

\section{Problem of Research}

The effectiveness of NGSS-oriented learning tools is measure through: (1) the increase in students' practice skill and responsibility significantly at the level of significance $\alpha=5 \%$; (2) the average level of students' practice skill determined by normalized gain value (average n-gain) at least in moderate category; and (3) the average level of students' practice skill is determined by equation: n-gain= (score posttest-score pretest) / (maximum score-pretest score) (Hake, 1999). According to the following criteria: (1) if $\mathrm{n}$-gain $\geq .7$ (high), (2) if $.3<\mathrm{n}$-gain $<.7$ (moderate), and (3) if $n$-gain $\leq .3$ (low). Therefore, the main problem of this research is to analyses the effectiveness of the students' practice skill by NGSS-oriented learning tools. 


\section{Research Focus}

The focus problem in this research includes: (1) whether there is a significant (statically) increase and responsibility before and after the NGSS-oriented learning tools is applied; (2) how much is the level of students' practice skill before and after the applied NGSSoriented learning tools, (3) whether there is an average difference in level of practice skill after learning with NGSS-oriented learning tools in all two groups.

\section{METHOD}

\section{General Background of Research}

This is a research and development study conducted at SMP Negeri 1 Wates, Kulon Progo, Daerah Istimewa Yogyakarta, Indonesia in February - March 2018. The scope of this research is the second-year students in academic year 2017/2018. Data used in this study was collected in the form of a questionnaire to reveal the feasibility of NGSSoriented science learning tools.

\section{Sample of Research}

The selection of samples is based the high classes. In this research populations were taken from 156 students at SMP Negeri 1 Wates, Kulon Progo, Daerah Istimewa Yogyakarta, Indonesia. The sample in this research were 52 students at SMP Negeri 1 Wates, Kulon Progo, Daerah Istimewa Yogyakarta, Indonesia, which arraged in the two groups: group-1 (students in class $8 \mathrm{D}$ ) and group-2 (students in class $8 \mathrm{E}$ ) Each groups consisted of 26 students who took Science subject in academic year 2017/2018.

\section{Instrument and Procedures}

NGSS-oriented learning tools can be used to improve the skill of developing and using models for students by the experimental method, with one experiment group and one control group. The experimental group used NGSS-oriented learning tools while the control group used the teacher's learning tools. The research location was SMP 1 Wates, Kulon Progo. The techniques of data collection used in this study were in form of observations of the developing and using models skill by an observer entered in an observation sheet during the science learning process. Data analysis included a percentage of students' developing and using models skill produced by descriptive statistics and comparing it to the skill of students in two groups, to find the best score between the experiment and control groups.

Table 3

Conversion of the Result of the Developing \& Using Models Skill

\begin{tabular}{cccc}
\hline No & Score Range & Category & Criteria \\
\hline 1 & $\mathrm{X} \geq 3$ & A & Very Good \\
\hline 2 & $3>\mathrm{X} \geq 2.5$ & B & Good \\
\hline 3 & $2.5>\mathrm{X} \geq 2$ & C & Fair \\
\hline 4 & $\mathrm{X}<2.5 \leq 2$ & D & Less \\
\hline
\end{tabular}

(Source: Djemari Mardapi 2008: 123) 
The developing and using models skill was said to have a better score in the experiment group than the control group.

\section{Data Analysis}

Data analysis performed included feasibility of NGSS-oriented science learning tools scored by two expert lecturers, one science teacher, and nine students, in a limited field test, to determine the response of students to developed worksheets. The validation of lesson plans and worksheets by questionnaire was done using four scale conversions (Mardapi, 2008). The assessment analysis used scale conversion by category. NGSSoriented learning tools in the form of lesson plans and worksheets are feasible for use in science learning if their average validation score is> 3.0. A developing-using models skill appraisal tool is feasible for use if the validation score is in a good category at 76$85 \%$.

\section{FINDINGS AND DISCUSSION}

The development of NGSS-oriented learning tools suitable for use in the science learning process is based on the assessment of the validators - two expert lecturers, one science teacher, and nine students. Expert lecturers who become validators are materials and media experts who can assess the feasibility of NGSS-oriented learning tools. Science teachers were also asked to assess whether NGSS-oriented learning tools are appropriate for use in classroom learning. Students were asked to assess the developed NGSS worksheet. The result of the feasibility of NGSS-oriented lesson plans is presented in Table 4.

Table 4

Result of NGSS-oriented Lesson Plan Assessment

\begin{tabular}{ccc}
\hline Assessment & Average & Criteria \\
\hline Step 1 & 3.65 & Very Good \\
\hline Step 2 & 3.82 & Very Good \\
\hline
\end{tabular}

Assessment of NGSS-oriented lesson plans was developed in two stages. The average assessment was made by expert lecturers and science teachers in the first stage and had a score of 3.65 with fairly to very good criteria. This score was sufficient to declare the developed lesson plan worth using (> 3.0), but revisions are required to perfect it. The developed lesson plan can be reassessed by the validator through a second stage assessment with revisions such as 1) learning objectives must be in accordance with the learning will be studied at that time, 2) instructional media used must be explicitly listed, 3) elements of skills to be achieved during the learning process had not appeared in learning objectives, 4) the NGSS framework must be subject-appropriate. The revised lesson plan was returned to the validator and science teacher for reassessment. The second stage validation result obtained a score of 3.82 which was very good. The results of the lesson plan assessment at this stage have shown that the NGSS-oriented lesson plan is suitable for use in science learning.

Learning tools developed in the form of NGSS-oriented worksheets were expected to improve students' developing and using models skill. The worksheet also underwent two 
stages of revision by expert lecturers and science teachers. The worksheet validation assessment is presented in Table 5.

Table 5

Result of NGSS Worksheet Assessment

\begin{tabular}{ccc}
\hline Assessment & Average & Criteria \\
\hline Stage 1 & 2.6 & Good \\
\hline Stage 2 & 3.36 & Very Good \\
\hline
\end{tabular}

Based on Table 4, the validation score of stage 1 of the developed worksheet obtained a score of 2.6, which is good. This means that the developed worksheet is not yet feasible for use. The worksheet required revisions to reach the expected score. Some worksheet revisions were 1) the picture on the worksheet was not clear (make bigger and clear), 2) the worksheet could have added more pictures to make it more interesting for students, 3) many used foreign terms and were better in Indonesian, 4) The worksheet title was not clear, 5) the background colour was not interesting, 6) the font style could be varied for important content. The revised worksheet was given back to the validator and science teacher for reassessment. The second stage validation result obtained a score of 3.36 which was very good. The results of worksheet assessment at this stage showed that NGSS-oriented worksheet is suitable for use in science learning.

The worksheet preparation had several requirements (Depdiknas, 2016). Some of these requirements included 1) didactic conditions that meant the worksheet could be used well for students at all levels of intelligence, 2) the use of language, sentence structure, vocabulary, level of difficulty, and clarity in the worksheet must be appropriate and understood by students, 3) the technical requirements including writing, drawing, and appearance. These three conditions could be used as a reference to assess the feasibility of NGSS-oriented worksheets. This was also a basic requirement for preliminary field testing involving nine students.

Preliminary field testing involved nine students in grade VIII of SMP Negeri 1 Wates, Kulon Progo who had different abilities. The group consisted of three high-ability, two medium-skilled, and three low-ability students. The result of preliminary field testing was expected to be a reference for whether developed worksheets could be used and understood by students with different abilities. The nine students involved in this test were randomly selected based on teacher input on the learner's ability in class. The results of preliminary field testing of the learner response to the developed NGSS worksheet are presented in Table 6.

Table 6

Preliminary Field Testing of NGSS Worksheet

\begin{tabular}{lcc}
\multicolumn{1}{c}{ Aspect } & Average Score & Criteria \\
\hline Worksheet layout and image & 3.33 & Very Good \\
\hline Table layout, drawings, and questions & 3.33 & Very Good \\
\hline $\begin{array}{l}\text { Display title, description, picture instructions, } \\
\text { tables, and questions }\end{array}$ & 2.89 & Good \\
\hline Language & 3.33 & Very Good \\
\hline Average Score & 3.22 & Very Good \\
\hline
\end{tabular}


In preliminary field testing, four aspects of the NGSS-oriented worksheet were assessed by the students. The average score of the four aspects was 3.22, a good score, meaning that the NGSS worksheet could be understood by low, middle, or high-ability students. Suggestions and advice given by the students about the worksheet could be used as revisions in Phase 2 before this worksheet is used in classrooms.

NGSS-oriented learning tools were expected to increase students' developing and using models skill after learning about the human respiratory system with these tools. This specific skill was also assessed with an observation sheet. Students would learn practical skill with characteristic materials. Developing and using models skill indicators are suitable for this theme, i.e., learning about the human respiratory system and developing a model. The feasibility of the developing and using models skill was also determined through two stages of revision. The validator assessed whether the formulated indicator was in accordance with the aspects of practical skills to be measured. The recapitulation of the validation results of the developing and using models skill observation sheet is presented in Table 7.

Table 7

Result of Developing and Using Models Skill Observation Assessment

\begin{tabular}{ccc}
\hline Assessment & Percentage $(\%)$ & Criteria \\
\hline Stage 1 & 88.9 & Very Good \\
\hline Stage 2 & 100 & Very Good \\
\hline
\end{tabular}

Based on the table, the healthy life questionnaire validation score in the first stage was $82.3 \%$, which was a good score. The results of this assessment should still have been revised according to suggestions from the validator. In the second validation stage, the score of the developing and using models skill observation sheet increased to $86.8 \%$, a very good score. Based on the validation, the observation sheet for measuring students' developing and using models skill was declared feasible for use in science learning.

NGSS-oriented learning tools consisting of lesson plans, worksheets, and the developing and using model skill are feasible for use in learning, based on results of expert validation (lecturers and science teachers). Consequently, NGSS-oriented learning tools can be used in class to measure students' practical skills. Practical skills are measured through the developing and using models skill, which has two indicators (Jancarikova, 2016). Developing-using models are measured by an observer using an observation sheet during the learning process. A summary of the results of practical skill measurements is presented in Table 8 .

Table 8

Developing and Using Models Skill Result

\begin{tabular}{clcc}
\hline No & \multicolumn{1}{c}{ Component } & Experiment Group & Control Group \\
\hline 1 & Number of Students & 27 & 26 \\
\hline 2 & Average Value & 3.69 & 1.58 \\
\hline 3 & Lowest Score & 3.13 & 1.38 \\
\hline 4 & Highest Score & 4.00 & 1.88 \\
\hline
\end{tabular}


A developing-using model is measured by an observer using an observation sheet during the learning process. Based on the summary of Table 8 , the average of the practical skill in the experiment and control class was different. The analysis results show that the experimental class had a very good score of 3.69 , meaning that there was a difference in the experimental class's practical skill of using NGSS-oriented learning tools. The control class had a score of 1.58 , which was low, meaning that the practical skills of experimental class students using NGSS-oriented learning tools were higher than those of the control class that used the teacher's learning tools instead of NGSS-oriented learning tools.

The developing and using models skill is one of the practical skills in the NGSS. It was chosen because it was appropriate for the material used to teach grade 8 students the human respiratory system. This skill could train students to inculcate the developing (making a human respiratory system replica) and using model skill (using Charta and torso). These learning tools are developed to prepare students to continue to further education based on the demands of the 21 st century.

Considering these views in developing NGSS-oriented learning tools the progression of science concepts across three grade bands identified in the NGSS is significant to help children understand science concepts at the suitable time. However, delaying the presentation of these concepts would adversely impact students' performance against international benchmarks (Qablan, 2018).

Teachers used scientific modelling in their science instruction. They had their students build models from investigations and interpret those models. They used the same debriefing questions with their students that we used in our workshops. Students anticipated these questions after building models and articulated their thoughts. Teachers described using models at various stages of inquiries in terms of the learning cycle. Teachers used models mostly at the Elaboration stage of the learning cycle, finding it a good place to ask students to apply their scientific knowledge. Teachers found scientific modelling to be useful in authentically assessing their students' understandings - they stated that it gave them a better picture of what students understood about the science than using more traditional assessments (Akerson, 2009).

\section{CONCLUSION}

In this paper, we presented the development of NGSS-oriented learning tools to measure students' practical skill. We also described the characteristics of these learning tools. From this study, we learned that the development of NGSS-oriented learning tools with a very good validation score can improve the quality of education, especially in terms of practical skill assessment. These learning tools can also train students in developing and using models and in the crosscutting concept. The experimental class had a higher score in the developing and using model skill using NGSS-oriented learning tools than the control class, 3.69 compared to 1.58 . Consequently, students became more concerned about their practical skill, especially developing and using models made of any material in the science classroom, using the NGSS. 


\section{ACKNOWLEDGEMENTS}

The author's gratitude goes to Ministry of Research, Technology and Higher Education Indonesia for funding the Research. Likewise, the author's gratitude goes to the Yogyakarta State University that has provided research opportunities.

\section{REFERENCES}

Akerson, Valarie. L., Townsend, J. S., Donnelly, L. A., Hanson, D. L., Tira, P., and White, O. (2009). Scientific Modeling for Inquiring Teachers Network (SMIT'N): The Influence on Elementary Teachers' Views of Nature of Science, Inquiry, and Modeling. J Sci Teacher Educ. 20, 21-40. https://doi.org/10.1007/s10972-008-9116-5.

Anindityas, Nurfa Anung., Utami, Nur R., \& Widiyaningrum, P. (2012). Penggunaan Alat Peraga Sistem Pernapasan Manusia. Unnes Science Education Journal USEJ 1 (2) (2012). http://journal.unnes.ac.id/sju/index.php/usej.

Atawi, Suparman. (2014). Desain Intruksional Modern. Edisi keempat. Jakarta: Erlangga.

Bybee, Rodger W. (2014). The Next Generation Science Standars and Life Sciences. The Association for Science Teacher Education, USA 2014. J Sci Teacher Educ, 25, 211-221. https://doi.org/10.1007/s10972-014-9381-4.

Duschl, Richard A. (2013). The Second Dimension-Crosscutting Concepts Understanding A Framework for. United State: K-12 Science Education. 11-12.

Depdiknas, Peraturan Menteri Pendidikan Nasional Nomor 22 Tahun 2016. (2016). Tentang Standar Isi Untuk Satuan Pendidikan Dasar dan Menengah. Jakarta: Depdiknas.

Gustafon, Brenda J., and Shanahan, Marie C. (2010). Children Thinking About Models: Analyzing A Globe. The Alberta Journal of Educational Research Winter 2010;56,4; Education Database pg.436.

Hendro, D and Jenny R.E. (1992). Pendidikan IPA. Proyek Pembinaan Tenaga Kependidikan Direktorat Jendral Pendidikan Tinggi Departemen Pendidikan dan Kebudayaan.

Hake, Richard R. (1999). Analyzing Change/Gain Scores. Accessed from http://www.physics.indiana.edu/ sdi/AnalyzingChange-Gain.pdf. At 9 December 2015, jam 18.50 WIB.

Jančařikova, Kateřina., \& Jančařik, Antonion. (2016). Work With Models In E-Learning Environments. Czech Republic: Faculty of Education, Charles University.

Krajcik, Joseph., Codere, S., Dahsah, C., Bayer, R., and Mun, K. (2014). Planing Intruction to Meet the Intent of The Next Generation Science Standards. J Sci Teacher Educ, 25, 157-175. https://doi.org/10.1007/s10972-014-9383-2. 
Lontok, Katherine S., Zhang, H., and Dougherty, M. J. (2015). Assessing the Genetics Content in the Next Generation Science Standards. PLoS ONE 10(7): e0132742. https://doi.org/10.1371/journal.pone.0132742.

National Research Council. (2014). Literacy for Science: Exploring the Intersection of the Next Generation Science Standards and Common Core for ELA Standards, A Workshop Summary. Washington, DC: The National Academies Press. https://doi.org/10.17226/18803.

National Research Council (NRC). (2011). A framework for K-12 science education: Practices, crosscutting concepts, and core ideas. Washington, DC: National Academies Press.

National Research Council (NRC). (2007) Taking science to school: Learning and teaching science in grades K-8. Washington, DC: National Academies Press.

National Research Council (NRC). (2008). Ready, set, science! Putting research to work in K-8 science class - rooms. Washington, DC: National Academies Press.

National Research Council (NRC). (2012). A Framework for K-12 Science Education: Practices, Crosscutting Concepts, and Core Ideas. Committee on a Conceptual Framework for New K-12 Science Education Standards. Board on Science Education, Division of Behavioral and Social Sciences and Education. Washington, DC: The National Academies Press.

National Research Council (NRC). (2013). Next Generation Science Standards: For States, By States. Washington, DC: The National Academies Press. https://doi.org/10.17226/18290.

Mardapi, Djemari. (2008). Teknik Penyusunan Instrumen Tes dan Non Tes. Yogyakarta: Mitra Cendekia.

Rosati, Jacky A., Burton, R., McGregor, G., McCauley., R., Tang, W., and Spencer, R. (2013). Development of A Three-dimensional Model of the Human Respiratory System for Dosimetric Use. Theoritical Biology and Medical Modelling, 10, 28. http://www.tbiomed.com/content/10/1/28.

Qablan, A. (2018). Comparison of Science and Engineering Concepts in Next Generation Science Standards with Jordan Science Standards. EURASIA J. Math., Sci Tech. Ed, 14(6), 2693-2709. https://doi.org/10.29333/ejmste/90267.

Woldemichael, Dereje E., and Hasim, Fakhruldin M. (2011). A framework for functionbased conceptual design support system. Journal of Engineering, Design and Technology Vol. 9 No. 3, 2011 pp. 250-272. Emerald Group Publishing Limited 17260531. https://doi.org/10.1108/17260531111179898. 